\title{
The Astray Belonging-The Perplexity of Identity in Paul Muldoon's Early Poems
}

\author{
Jing YAN \\ Sichuan Agricultural University, Dujiangyan, Chengdu, Sichuan Province, China
}

Keywords: Paul Muldoon, Northern Ireland, Identity, Perplexity.

\begin{abstract}
As a poet born in a Catholic family in Northern Ireland but deeply influenced by the British literary tradition, Paul Muldoon's identity is obviously multiple and complex especially from 1970s to 1980s when Northern Ireland was going through the most serious political, religious and cultural conflicts, all of which were unavoidably reflected in the early poems of Paul Muldoon. This thesis attempts to study the first four anthologies of Paul Muldoon from the perspective of Diaspora Criticism in Cultural Studies to discuss the issues of identities reflected in Muldoon's poems. Obviously, the perplexity triggered by identities is not only of the poet himself but also concerning Northern Irish issues. Muldoon's poems relating cultural identities present the universal perplexity of Irish identity.
\end{abstract}

\section{Introduction}

While Ireland is a small country in Western Europe, this tiny piece of magical land has given birth to countless literary giants. From Jonathan Swift and Richard Sheridan in the 18th century, to Oscar Wilde in the 19th century and all the way to James Joyce, George Bernard Shaw, Butler Yeats, Samuel Beckett and Seamus Heaney in the 20th century, there are countless remarkable Irish writers who help to build the reputation of Irish literature. Since 1960s or 1970s, the rise of Irish poetry began to draw world attention, particularly after poet Seamus Heaney won the Nobel Prize for Literature in 1995, Following Heaney, the later poets in Ireland are also talented in poetic creation, of whom ,the 2003 Pulitzer Prize winner Paul Muldoon is undoubtedly a prominent representative. Muldoon is considered to be the most outstanding poet after Heaney in contemporary Northern Ireland. Heaney's peer, Irish poet Michael Longley also spoke highly of Paul Muldoon: "I couldn't think of any other writers who have the insightful vision as Muldoon does [1]." In 2002, poet Paul Muldoon was highly praised by Times Literary Supplement as "the greatest English poet born since World War II" [2].

However, Muldoon's literary achievements and impacts have not been fully recognized by domestic researchers. According to CNKI (Chinese National Knowledge Infrastructure) statistics, so far there are only seven relevant articles published of which the first was issued on Masterpiece Appreciation (Vol.10, 2007) by Li Xinde entitled 'Marginalized Identity: National Identity in Paul Muldoon's Poetry" in which the author focuses on talking about the issue of distinctive national identity in Muldoon's poetry and points out the national identity issue in his poems is closely related to the Northern Ireland peace process. This article, however, with four poetry anthologies of his early works as research object, is trying to apply the dispersed perspective of cultural studies to investigate the identity issue in Muldoon's poetry. 


\section{Identity Perplexity Resulting from Political Belonging}

In 1951, Muldoon was born in County Armagh, Northern Ireland in a Catholic family. It is known to all that since 1921, Northern Ireland has been politically under the governance of UK and hence has become part of the United Kingdom of Great Britain and Northern Ireland. However, geographically, the mountains and rivers of Northern Ireland and the Irish Republic in the south can not be separated and culturally the two regions are so intimately interdependent that the ownership of Northern Ireland in the Catholic-dominated island of Ireland has become so complicated and confusing in terms of Irish identification.

Such identity perplexity was reflected in a poem entitled "Blemish" in his second collection of poems Mules[3] in which he euphemistically rendering the multiplicity of identities by way of writing a baby girl born with deformity in her eyes. He wrote:

Were it indeed an accident of birth

That she looks on the gentle earth

And the seemingly gentle sky

Through one brown and one blue eye. (Muldoon 2001: 57)

Born in Country Armagh, a small town that belongs to Northern Ireland, the poet was no doubt in an embarrassed identity. He is an Englishman but his life is closely related with the Republic of Ireland. So he experienced something as exile, a kind of betweenness and verge living. Muldoon exhibited the perplexity of the political belongingness of Northern Ireland in this short poem implicitly as a way to display his own perplexed national identity.

At the very beginning of the poem, our poet described the unfortunate experience of the baby girl who was born with two distinctive eyes. When she uses her unique eyes to observe the land and sky, what kind of scene will be seen?

The baby girl is unusual for she has two distinctive eyes, one is brown and the other is blue which indicates she was born with two different backgrounds. With two entirely different eyes, the girl feels rather embarrassing and confusing to look upon the world and recognize her own identity. She could neither see the brown earth nor the blue sky clearly with her eyes respectively. The word "gentle" used in the verse is rather striking in that we cannot help associating "gentle" with "gentleman", a word which is closely related with Britain. If we investigate the source of gentleman, we will find that the word gentleman first appeared in Western Europe in the 17th century evolving from chevalier a word which signifies courage, courtesy, justice and readiness to help the weak and then prevailed and prospered in Britain as the embodiment of British national culture. The use of the word gentle here is of deep implications as it alludes to Britain. So what the baby girl looks upon in this poem is the gentle British earth and the seemingly gentle British sky.

The reason why our poet observed the bitter experience of the girl so carefully was that there's extreme similarity between what the baby girl suffered and what Muldoon's nation-Northern Ireland was going through and his own identity crisis as a Northern Irishman. Muldoon's hometown Northern Ireland was under the reign of UK politically but it was no easy task for the North to break up with the South completely as both had the same origin. Born in a place with awkward status suffering from political conflicts, Muldoon himself was confused with his own cultural identity. So what is exactly behind the confusion and perplexity of our poet?

According to professor Tong Ming from the University of California, Los Angeles, U.S., even if one was not living in the diasporic condition, he or she could still learn to write and think with diasporic perspective [4]. This is the case of poet Muldoon. 
Although he himself was not in the diasporic living condition, however in the realm of spirit, he is a Diaspora and the confusion that he has experienced is resulted from his diasporic experience. Born in Northern Ireland, a politically awkward place, Muldoon hovered between dual ownership. Just as Edward Said pointed out in his Reflections on Exile and Other Essays, the Diasporas usually sink into a kind of betweenness where they can neither completely break up with their native culture nor totally involve in the new culture, so they wander about the cracks between the two cultures. People usually think the Diasporas belong to the context they are in, but they themselves feel incompatible, always hovering between two cultures [5]. As Muldoon has mentioned, Northern Ireland was in the betweeness as it is politically under the reign of UK but inseparable with Southern Ireland in terms of historical and cultural relations, in how would it feel when looking at the British soil and sky?

Muldoon's "travel-style thinking perspective was achieved via crossing national and ethnic boundaries in the realm of spirit'[6]. He was not restricted by any kind of stance, rather, frustrated by his national identity due to the dilemma of political status. At the very beginning of the poem, the poet wrote, "Were it indeed an accident of birth?" On the one hand, as is used herein, an interrogative, we can see the poet's attitude is uncertain and he is confused with his own cultural identity; On the other hand, the British high-handed policy on the Northern Ireland is obviously not gentle at all. The word" accident" reveals the poet's heart-felt pain which stems from his struggling between double identities. Muldoon's confusion and struggling, his quest for cultural identity is the reflection of the awkward position of Northern Ireland.

In the title poem "Mules" of the same collection, Muldoon drew concerns about his specific national identity by way of writing the birth of mules. In the first line, he sighed with great pity: "Should they not have the best of both worlds?" The mules Muldoon described here is the offspring of the cross of horses with donkeys, so in Muldoon's eyes they deserved to have the strong body inherited from the horses and the deftness and diligency from the donkeys, so the mules were suppose to have the best of both worlds. However, the poor mules were mercilessly deprived of the reproductive capacity ever since they were given birth and were endowed with an awkward identity.

Muldoon took a look at his own family background in the light of the birth of mules and revealed his troublesome national identity as a Northern Irish. Just as the poem indicates, Northern Ireland should have the best of the two worlds, the eminent qualities of both Britain and Ireland. But as a matter of fact, it was in great torment of warfare and sharp conflicts triggered off by the political belongingness of the territory and the people were also struggling fiercely in despair which frustrates Muldoon a lot. So he chose to stay in the betweenness, a middle state 1 introduced by Said in which one can neither easily get rid of the old culture nor totally involve in the new one. In the third stanza of "Mules", Muldoon wrote: "We had loosed them into one field./ I watched Sam Parsons and my quick father/ Tense for the punch below their belts, / For what was neither one thing or the other. Placed in dilemma, Muldoon had no alternative in pursuing his own national identity. The word "punch" is of crucial meaning here. Literally, punch refers to driving cattle but in a deep sense, it alludes to suppression for the North in the political level which caused the awkward political situation of Northern Ireland. Or one thing, under the leadership of Britain and in an inferior status, it underwent suppression; for another, it was hard to remedy the

\footnotetext{
1 The betweeness mentioned here refers to the situation of a certain culture when diverse cultural exchanges appear discussed in Homi K. Bhabha' s The Location of Culture
} 
long-term historical trauma with the Republic of Ireland. Staying in the so-called betweeness, the poet can see his national identity in a crystal clear way. By way of writing the awkward birth of the mules, Muldoon's perplexed national identity is presented, which, to a larger degree, is the perplexity of Northern Ireland in sense of political ownership.

\section{Perplexed Identity Due to Minor Religious Belief}

Of all the residents in Northern Ireland, more than $60 \%$ are the migrant descendents from England and Scotland who believe in Christianality, the national religion of Britain and about $30 \%$ are the Irish natives who pursue Catholicism [7]. Though politically belonged to Britain, the peaceful and friendly coexistence seemed impossible for Protestants and Catholics because of the radical differences and resistances between the two. The Protestants in the North strongly advocated that Northern Ireland stay as part of the UK while the Catholics demanded that it should break away from the ruling of Britain and reunite with the Republic of Ireland. As the Protestants belong to the majority and possess more political power, North remained as part of UK which resulted in the separation of Ireland and the long-term violent turmoil in the Ulster area. Since 1960s, in particular, when the bloody events occurred, the conflicts between the two religious groups never ceased. Of all the sensational events, the Bloody Sunday occurred in 1972 was the most renowned. On January 30th, 1972, a large-scale demonstration was organized in Derry, Northern Ireland by the Catholics to protest against the policy executed by the British government in Northern Ireland of taking suspects into custody at their own will without sentence. During the process of parade, 13 innocent civilians were shot to death by the British army which caused a series of tragic events in North and almost led to the civil war.

Our poet Muldoon was just born in a Catholic family in the turbulent area in Northern Ireland. In a Protestants-dominated region, with the minor religious birth, Muldoon deeply felt the disaster brought about by the denominational clashes since he was a little boy. In an exclusive interview with BBC, when asked if his life and family were influenced by his minor religious belief, Muldoon confessed "I think anyone from that part of the world has been, you know, profoundly affected by the depth of their experience." "2Muldoon witnessed the tragic scenes brought about by the violent clashes since his was young, so he was strongly against violence in any form. As for the sectarian conflict and bloodshed took place in his hometown, he did more than just stand on his own stance as a Catholic identity for his sect and for himself, rather, he said in an interview, "I can see arguments on both sides as it were there. And I, frankly I think that's one of the things we have to pursue, all of us. We have to imagine, no matter where we come from, which side we're on as it were, what it's like to be on the other side," 3 Muldoon objectively see the starting points and opinions of the two parties involved in the conflicts, but at the meantime, he also felt the long-range unfair and ferocious treatment that Catholics were coped with. Our poet was in a difficult stance as he felt the confusion the sectarian conflicts brought about to his national identity. Therefore, Muldoon chose to reflect the whole situation by reminding the common people the bloodshed and killing brought about by religious conflicts in Northern Ireland.

In "Clonfeacle" a poem from New Weather (1973), Muldoon wrote:

It happened not far away/ In this meadowland/ That Patrick lost a tooth./ I translate

\footnotetext{
2 This is from the BBC exclusive interview that Muldoon had with John Tusa

Also from the BBC exclusive interview that Muldoon had with John Tusa
} 
the placename/ As we walk along/ The river where he washed, / That translates stone to silt./ The river would preach/ As well as Patrick did./ A tongue of water passing/ Between teeth of stones,/ Making itself clear,/ Living by what it says,/ Converting meadowland to marsh./You turn towards me,/ Coming round to my way/ Of thinking, holding/ Your tongue between your teeth./ I turn my back on the river/ And Patrick, their sermons/ Ending in the air./ (Muldoon 2001:12)

In the poem, the uncertainties about love and self between two lovers were written as the reflection of worries about the prospect and destiny of Northern Ireland resulting from sectarian strife. Muldoon cited the missionary experience of saint Patrick, the Irish patron saint. Patrick was the first to spread Christianity into Ireland in 5 A.D.and he dedicated himself to the dissemination of religious rays and hopes over the whole Ireland ever since. Muldoon first wrote about Patrick's mission and associated it with the river which was able to preach as what Patrick did because it owned one tooth lost by Patrick. The river changed everything in nature, for instance, "That translates stone to silt." or "Converting meadowland to marsh." However, the young lovers after listening to the Saint's preachment reacted "of thinking, holding your tongue between your teeth." "I turn my back on the river". All above reflected the lovers' puzzlement about their love as neither of them was willing to convert his or her own belief and stance. Perhaps the two lovers were in deep love but were from two distinctive religious backgrounds so an unbridgeable gulf lay between them. The last stanza "And Patrick, their sermons ending in the air" needs to be carefully analyzed as besides the literary meaning, "in the air" can also refer to something uncertain and is hung in doubt which indicates that on the one hand, the conflicts between the two religious groups with old scores were far from over; on the other, the worries about the sectarian disputes of Northern Ireland and his own national identity were exhibited. By citing St. Patrick's missionary experience, Muldoon described the confusion of the young man and woman so as to reflect the perplexity of people in Northern Ireland in terms of religious beliefs. Muldoon was located in a complex situation, a liminal space where he was both a Catholic minority badly treated and persecuted by the Protestants and a poet who should be tolerant and rational towards the conflicts caused by different sectarian stances. So he was puzzled about how to find a way out for both Northern Ireland and his own hybrid national identity. What he emphasized here was that the hatred and opposition between different religious beliefs were irreconcilable in the North as the result of colonial evil, so even Saint Patrick was not able to heal people's religious differences and conflicts. The confusion was the true reflection of the current situation in Northern Ireland. However, under the reign of the Union, the Northern Ireland had to experience the baptism of British culture which was displayed in the facet of language at first.

\section{Conclusions}

From the above-mentioned, Muldoon's early poems were the reflection of his perplexity of national identity with regard to the political status and religious beliefs in the Northern Ireland. Muldoon's depiction of his own identity crisis was in reality his concern about the severe political and religious conflicts in the North from 1970s to $1980 \mathrm{~s}$. His poems in this period aimed at reminding people the astray belonging of the North and drawing people's attention to the awkward situation in Northern Ireland and making efforts together to find a way out for its future. In1987, Muldoon and his family emigrated to the United States and settled down in New Jersey. Since then some identity changes appeared in Muldoon's poems which would be talked about 
later in monographs.

\section{References}

[1] Robert Potts. The Guardian Profile: Paul Muldoon ---The poet at play Guardian, 12/5/2001.

[2] Robert Macfarlane. Times Literary Supplement, 11/10/2002.

[3] Paul Muldoon. Poems 1968-1998 [M]. United Kingdom: Faber\&Faber, Limited, London, 2001

[4] Tong Ming. Diaspora [J]. Foreign Literature, 2004(6). (In Chinese)

[5] Said, Edward. Reflections on Exile and Other Essays [M]. Cambridge Harvard University Press, 2002.

[6] Zhao Yifan, Zhang Zhongzai, Li De'en. Key Words to Western Literary Theories[C].Beijing: Foreign Language Teaching and Research Press, 2005. (In Chinese)

[7] Wang Lian. On World Nationalism [M]. Beijing: Peking University Press, 2002. (In Chinese) 